\title{
PENGARUH PENDIDIKAN AGAMA ISLAM TERHADAP PERILAKU AKHLAK SISWA (KARAKTER)
}

\author{
H. Suhada ${ }^{1}$ \\ Arief Saptono $^{2}$ \\ Ageng Setiani Rafika ${ }^{3}$ \\ Dosen AMIK Raharja Informatika ${ }^{1}$, Dosen STMIK Raharja ${ }^{2,3}$ \\ Jl. Jendral Sudirman No. 40, Modern Cikokol, Tangerang ${ }^{1,2,3}$ \\ Email : suhada@raharja.info ${ }^{1)}$, arief.saptono@raharja.info ${ }^{2)}$, agengsetianirafika@raharja.info ${ }^{3)}$
}

\begin{abstract}
ABSTRAK
Pengaruh Pendidikan Agama Islam Terhadap Perilaku Akhlak Siswa (karakater) SMPN 23 Kota Tangerang

Penelitian ini dilatarbelakangi oleh suatu permasalahan atau fenomena anak usia sekolah SMP yang berkelakuan tidak sebagaimana mestinya sebagai anak pelajar, karena ada diantara siswa yang merokok, berlaku tidak sopan, berbicara kasar, bolos sekolah, malas belajar dan lain-lain. Permasalahan yang diungkap dalam penelitian ini adalah bagaimana pengaruh pendidikan agama islam memberikan dampak kepada siswa dalam berperilaku baik dan sopan sebagaimana diharapkan. Tujuan yang hendak dicapai adalah untuk mengetahui seberapa besar pengaruh pendidikan agama islam dalam membentuk perlaku akhlak siswa (karakter) sebagai mutu pembelajaran. Penelitian ini merupakan penelitian kuantitatif dengan jenis korelasional. Subjek penelitian adalah siswa siswi SMPN 23 Tangerang kelas 8 dan kelas 9 tahun ajaran 2013/2014 sejumlah 105 siswa dari populasi 1425 siswa. Berdasarkan analisis penelitian bahwa variabel pengelolaan pembelajaran yang baik memberikan pengaruh yang signifikan terhadap mutu pembelajaran (perilaku siswa).
\end{abstract}

\section{ABSTRACT}

Description of Islamic Education on Student Moral Pattern (karakater) SMPN 23 Kota Tangerang This study is motivated by problems or junior high school students who are not in accordance with the students, because there are differences in students, smoking is not polite, rude, skipping school, lazy learning and others. The problem revealed in this study is how the benefits of Islamic religious education for students. The goal to be achieved is to know the meaning of Islamic religious education in the form of moral behavior (character) as the quality of learning. This research is a quantitative research with correlational type. The subjects of the study were students of SMPN 23 Tangerang class 8 and grade 9 of academic year 2013/2014 from 105 students from population 1425 students. Analysis of learning variable are good and give a significant effect on the quality of learning.

\section{A. Latar Belakang}

Era globalisasi, era dimana orang bisa melihat dunia hanya sebesar layar laptop atau layar tv terlebih lagi pengetahuan yang berkembang dengan sangat pesat, teknologi elektronik, media dan sumber pengetahuan bisa diakses dengan sangat mudah, bukan hanya perkembangan positif yang dapat dilihat tetapi juga perkembangan negatif.

Sehingga apabila seseorang tidak membekali diri dengan pengetahuan agama maka dia akan lebih banyak condong kedunia maksiat dan keluar daripada jalan taqwa, orang 
lebih senang ketempat hiburan, mall dan tempat-tempat yang dianggapnya modern menurutnya hawa nafsunya, dan mereka enggan untuk datang ke majlis-majlis ilmu.

Fenomena tersebut di atas, hampir hampir setiap hari atau bahkan setiap saat dapat disaksikan dimana-mana baik di desa maupun di kota, dan yang lebih memilukan lagi semua kalangan usia baik orang tua (dewasa), remaja, anak-anak, laki-laki dan perempuan semua ikut bergabung didalamnya. Sungguh fenomena yang sangat memilkukan hati orang-oranga yang beriman.

Mereka lebih senang berada di tempat maksiat daripada tempat-tempat yang baik, mereka lebih senang datang ketempat hiburan daripada ke majlis ta'lim atau ke sekolah, mereka lebih senang bermain daripada belajar, mereka lebih senang melihat artis daripada melihat kyai atau ustadz dan guru, sehingga mereka semakin jauh saja dari cahaya kebenaran bahkan dekadensi moral semakin banyak disaksikan di mana-mana, dari yang tua sampai yang muda, dari yang dewasa sampai anak-anak, termasuk anak- anak usia sekolah terutama siswa SMP berada didalamnya.

Mereka ibarat seumur jagung masa depan yang baik menantinya, akan tetapi karena kurang pengawasan dan salah pergaulan, kurang pendidikan agama, akhirnya mereka banyak melakukan hal- hal yang melanggar atura- aturan agama dan norma-norma sosial diantaranya: tidak patuh terhadap orang tua dan guru, tidak melaksanakan shalat, malas belajar, senang main game, ucapannya jauh dari sopan santun, perangainya buruk, sering marah atau tempramental, suka merokok, tawuran antar sekolah, nongkrong di pinggir jalan bahkan mereka sudah berani melakukan tindakan kriminal seperti melakukan pemalakan dan mengambil barang orang lain yang bukan miliknya dan masih banyak lagi perilaku buruk lainnya.

Dengan memperhatikan hal tersebut di atas penulis merasa perlu mengadakan penelitian, hal-hal apa saja yang membuat mereka melakukan semua itu. Penelitian yang dimaksud adalah penelitian terhadap perilaku akhlak siswa SMP.

Seberapa besar pengaruh Pendidikan Agama Islam di sekolah terhadap perilaku akhlaq Siswa SMP di Kota Tangerang.

\section{B. Metode Penelitian}

Metode penelitian yang digunakan adalah metode penelitian kuantitatif dengan jenis korelasional, namun demikian dalam penelitian ini juga menggunakan pengkayaan dengan statistik deskriptif untuk hal- hal tertentu yang diperlukan.

Langkah-langkah awal yang digunakan dalam penelitian ini alat bantu analisa statistik deskriptif sebagai dasar awal penganalisaan. Dengan demikian analisa diawali dengan melihat kecenderungan keterkaitan antar fenomena amatan, setelah pendekatan kuantitatif deskriftif dilakukan quesioner maupun menggunakan data pendukung lainnya. Analisa lebih lanjut dilakukan dengan melihat kecenderungan hubungan antar fenomena yang dilakukan dengan menggunakan analisis inferensial.

Secara korelasional penelitian ini mencoba menggali wacana konsep pembelajaran pendidikan agama Islam terhadap perilaku akhlak siswa. Penelitian ini mengambil lokasi SMPN 23 Kota Tangerang. 


\section{PENELITIAN YANG RELEVAN}

Adapun penelitian yang relevan dengan penelitian ini adalah sebagai berikut:

1. Sri Sapitri Aryanti ${ }^{1}$, Pengaruh Aktivitas Pembelajaran Pendidikan Agama islam Terhadap Akhlak Siswa(Penelitian di SMP Negeri 3 Karang Pawitan Garut) penulis berkesimpulan adanya pengaruh aktivitas pembelajaran Pendidikan Agama Islam terhadap akhlak siswa di SMP Negeri 3 Karangpawitan Garut.

2. Mukhlisin ${ }^{2}$, Pengaruh Pemahaman PAI Terhadap Perilaku Sosial Siswa di SMK Unggulan NU Mojoagung Jombang, penulis berkesimpulan terdapat pengaruh yang positif dan signifikan antara pemahaman Pendidikan Agama Islam terhadap perilaku sosial siswa di SMK Unggulan NU Mojoagung Jombang.

3. Syaiful Anwar ${ }^{3}$, Peran Pendidikan Agama Islam Dalam Membentuk Karakter Bangsa, penulis berkesimpulan Pendidikan agama memegang peranan penting dan inti pendidikan karakter itu sendiri, karena itu pendidikan agama agar baik pada level sekeolah maupun rumah tangga perlu mendapat perhatian scara sungguh-sungguh, sehingga moral/akhlak Bangsa menjadi lebih baik dimasa yang akan mendatang.

\section{Perilaku Akhlaq Siswa}

Kata"perilaku" terdiri dari dua kata peri dan laku yang dalam kamus bahasa Indonesia mempunyai arti perbuatan, kelakuan atau tingkah laku. ${ }^{4}$ Jadi perilaku itu adalah perbuatan, kelakuan dan tingkah laku seseorang. Sedangkan kata "akhlaq " diambil dari bahasa arab artinya: khaluqa, yakhluqu, khuluqan bentuk jama' kata khuluqon adalah akhlaq artinya: pantas, patut, perangai baik, budi pekerti. ${ }^{5}$ Secara Istilah akhlak adalah perangai baik, budi pekerti seseorang yang pantas dan patut di contoh dalam kehidupan sehari-hari.

Siswa ialah pelajar ${ }^{6}$ satu, beberapa orang, atau sekelompok orang yang sedang mempelajari ilmu atau bimbingan belajar dari seorang guru, atau orang yang berada dalam kelompok belajar dalam pembelajaran suatu disiplin ilmu baik formal maupun non formal. Jadi Perilaku Akhlaq siswa ialah Budi pekerti yang luhur (mulia) atau perangai baik yang dilakukan oleh seseorang, beberapa orang atau sekelompok orang yang sedang dalam pembelajaran suatu disiplin ilmu, baik formal maupun non formal yang pantas dan patut dijadikan contoh teladan buat orang lain.

1.Sri Sapitri Aryanti, Pengaruh Aktivitas Pembelajaran Pendidikan Agama islam Terhadap Akhlak Siswa(Penelitian di SMP Negeri 3 Karang Pawitan Garut) Jurnal Pendidikan Universitas Garut Fakultas Pendidikan Islam dan Keguruan Universitas Garut ISSN: 1907-932X 44

2 Mukhlisin, Pengaruh Pemahaman PAI Terhadap Perilaku Sosial Siswa di SMK Unggulan NU Mojoagung Jomban, Jurnal Pendidikan Islam (E-ISSN: 2550-1038), Vol. 1, No. 2, Desember 2017, Hal. 215-234. Website: journal.Unipdu.ac.id/index.php/jpi/index.

3 Syaiful Anwar, Peran Pendidikan Agama Islam Dalam Membentuk Karakter Bangsa, Al-Tadzkiyyah: Jurnal Pendidikan Islam, Volume 7, November 2016 P. ISSN: 20869118 E-ISSN: 2528-2476 157 4W.J.S. Purwadarminta, kamus umum bahasa Indonesia, Balai pustaka, Jakarta,Tahun 1991 h. 738.

5Ahmad Warson Al Munawir, Kamus Bahasa Arab Indonesia, Yogyakarta: Pustaka Progresif, Tahun 1997,h. 364.

6 W.J.S. Purwadarminta, Kamus umum bahasa Indonesia,...h. 955. 
Dalam hal yang berkaitan dengan perilaku akhlak siswa, pembelajaran pendidikan agama Islam harus benar-benar mendapat perhatian yang sangat tinggi, baik pihak dari pengelola sekolah seperti kepala sekolah, guru maupun intrumen-intrumen lain yang ada di sekolah. oleh karenanya pembelajaran agama islam harus di susun dengan kurikulum yang sebaik-baiknya demi untuk mencapai tujuan dari pendidikan agama Islam itu sendiri.

Adapun tujuan dari pendidikan agama Islam adalah mencapai akhlaq al-karimah (akhlak mulia), sebagaimana di jelaskan oleh M. Athiyah al- Abrasyi, bahwa :

“ Tujuan utama dari pendidikan agama Islam ialah pembentukan akhlak dan budi pekerti yang sanggup menghasilkan orang-orang yang bermoral, laki-laki maupun wanita, jiwa yang bersih, kemauan keras, cita-cita yang benar dan akhlak yang tinggi, tahu arti kewajiban dan pelaksanaannya, menghormati hak-hak manusia, tahu membedakan buruk dengan baik, memilih suatu fadhilah karena cinta pada fadhilah, menghindari perbuatan yang tercela karena ia tercela, dan mengingat Tuhan dalam setiap pekerjaan yang mereka lakukan". 4

Dari pendapat M. athiyah diatas dapat diambil kesimpulan bahwa pendidikan agama islam terhadap anak bertujuan untuk membentuk akhlak mulia pada saat sudah dewasa nantinya. Sebagaimana nabi Muhammad saw, bersabda: Dari Abu Hurairah Radhiyallahu 'anhu.

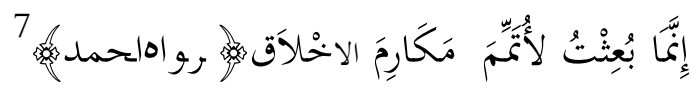

Sesungguhnya saya diutus kedunia untuk menyempurnakan budi pekerti yang mulia.

Melihat maksud hadits nabi Muhammad saw bahwa nabi diutus kedunia adalah untuk memperbaiki akhlak manusia yang pada saat itu berada dalam kegelapan ( jahiliyah ) dan para pakar pendidikan Islam mengacu kepada hadits nabi diatas bahwa tujuan pendidikan islam adalah untuk membentuk akhlaq al-karimah siswa.

Berkaitan dengan akhlak, pendidikan agama Islam, harus dikembangkan sesuai dengan tujuan atau sasaran. Karena itu pengembangan kurikulum merupakan bagian yang esensial dalam proses pendidikan. Sasaran yang dicapai bukan semata-mata memproduksi bahan pelajaran, melainkan lebih dititikberatkan pada peningkatan kualitas pendidikan. Sebagaimana diungkapkan oleh Sukmara:

“ Pengembangan kurikulum merupakan suatu proses merencanakan dan menghasilkan suatu alat yang lebih baik dengan didasari hasil pengkajian terhadap kurikulum yang telah berlaku sehingga dapat memberikan kondisi belajar-mengajar lebih baik dan berkualitas ". 8

Melihat pendapat Sukmara diatas, kurikulum di pandang sebagai alat untuk mencapai tujuan pendidikan sehingga dituntut memiliki sifat anticifatory, bukan hanya sebagai reportorial. Hal ini berarti harus dapat " meramalkan " kejadian masa mendatang, tidak hanya bisa melaporkan keberhasilan belajar peserta didik saat itu ataupun masa lalu.

Pengembangan kurikulum mempunyai dua makna, yakni penyusunan kurikulum yang sama sekali baru ( Curriculum construction ) dan penyempurnaan kurikulum yang telah ada ( Curriculum Improvement).

7 Ahmad bin Hambal, Musnad Ahmad, jilid II, h. 381, Al-Bukhari dalam al-Adabul Mufrad no. 273 (Shahiihul Adabil Mufrad no. 207), Ahmad (II/381), dan al-Hakim (II/613)

8. Dian Sukmara, Implementasi Life Skill dalam KTSP, Mugni Sejahtera, Tahun, 2007, h. 9. 
Sejalan dengan pengembangan kurikulum, bagaimana tentang kurikulum pendidikan agama Islam? dalam sejarah diterangkan bahwa kurikulum pendidikan agama Islam diwaktu dulu tidak tertentu atau terikat dengan sekian jam untuk suatu mata pelajaran dalam seminggu seperti sekarang ini, tetapi pelajaran dulu itu adalah umum sifatnya dimana guru atau juru didik punya kebebasan memilih buku dan bahan-bahan pelajaran yang akan diajarkannya. Seperti Umar bin Khatab di dalam Al- Abrasyi, telah menulis kurikulum berikut dan mengirimkannya kepada penguasa-penguasa Islam, yang berbunyi: "Ajarkanlah anak-anak kamu berenang, berkuda, sampaikan kepada mereka pepatahpepatah yang berlaku dan sajak-sajak yang terbaik".9"

Kalau diperhatikan dengan seksama bahwa perkataan Umar bin khotob terhadap penguasa- penguasa Islam pada zaman itu, sudah mulai menyusun kurikulum walaupun kurikulum yang dimaksud belum bersifat khusus seperti sekarang ini.

Sedangkan kurikulum pendidikan agama Islam pada saat sekarang ini, M. Athiyah alAbrasyi, membagi kepada tiga tingkatan diantaranya:

Pertama, Untuk anak-anak dalam tingkat pertama atau permulaan secara umumnya adalah sebagai berikut : Al Qur'an dan sendi-sendi agama, membaca, menulis, berhitung, bahasa, sajak,-sajak yang mengandung ajaran-ajaran akhlak, menulis baik, cerita-cerita, latihan berenang dan naik kuda. Kedua, Untuk remaja ( menengah ), kurikulumnya adalah belajar pidato, belajar sejarah, terutama sejarah-sejarah peperangan, tata tertib bersidang, serta memperhatikan pula bahan-bahan pelajaran pokok diatas. Ketiga, kurikulum perguruan tinggi Islam mencakup ilmu-ilmu eksakta, sastera, kajian-kajian ilmiah, filsafat, kedokteran, ilmu agama

(akhlak) dan lain-lain. ${ }^{10}$

Akan tetapi dalam pendidikan moral dan akhlak dalam Islam ada beberapa metode, seperti yang diungkapkan oleh M. Athiyah al-Abrasyi, antara lain sebagai berikut :

a. Pendidikan secara langsung, yaitu dengan cara mempergunakan petunjuk, tuntunan, nasehat, menyebutkan manfaat dan bahayanya sesuatu, di mana para peserta didik di jelaskan bahaya-bahayanya sesuatu dan akibatnya, juga di jelaskan hal-hal manfaat sesuatu dan pahala atau manfaatnya, serta mendorong mereka berbudi pekerti yang luhur dan menghindari hal-hal yang tercela.

b. Pendidikan akhlak secara tidak langsung, yaitu dengan jalan mendiktekan sajak-sajak yang mengandung hikmat kepada peserta didik, memberikan.

c. nasehat-nasehat dan berita berharga, serta mencegah mereka daripada melakukan hal-hal yang tercela.

d. Mengambil manfaat dari kecenderungan dan pembawaan anak-anak dalam rangka pendidikan akhlak. Seperti contoh mereka senang meniru ucapan-ucapan, perbuatanperbuatan, gerak-gerik orang-orang yang berhubungan erat dengan mereka. Oleh karena itu filosof-filosof Islam mengharapkan kepada setiap guru agar supaya mereka berhias dengan akhlak yang baik, mulia dan menghindari setiap yang tercela. ${ }^{11}$

Dengan memperhatikan metode pembelajaran akhlak tersebut di atas, maka pembelajaran akhlaq al- karimah akan dapat tercapai bukan hanya anak menjadi baik akhlaknya juga akan menjadi cerdas emosional intelegensinya sampai anak tumbuh dewasa kelak, sehingga anak akan menjadi orang yang beruntung, bahagia dunia akhirat.

9. M. Athiyah al- Abrasyi alih bahasa, A. Gani dan Djohar Bahry, Dasar-Dasar Pokok Pendidikan Islam, PT.Bulan Bintang,jakarta, 1970. Hal, 163.

10. M. Athiyah al- Abrasyi, Alih Bahasa A.Gani dan Djohar Bahri... 1970, hal.163.

11. M. Athiyah al- Abrasy,alih bahasa, A. Ghani,dan Djohar Bahri, ... hal.105-109. 


\section{Variabel Penelitian}

1. Klasifikasi variabel

Variable penelitian ini terdiri dari 2 variabel dan 1 variabel terikat dengan penetapan sebebagai berikut :

a. Aspek perilaku akhlak sebagai variabel terikat ( Y )

b. Aspek pengelolaan pembelajaran tergolong dalam variable bebas (X)

2. Definisi konseptual

a. Perilaku akhlak adalah gambaran dan karakteristik sekolah yang menunjukan kemampuan untuk memenuhi kebutuhan dalam pencapaian tujuan.

c. Pengelolaan pembelajaran pendidikan agama islam yaitu segala aktivitas yang dilakukan oleh guru dalam melaksanakan interaksi belajar.

\section{E. Populasi dan Sampel Penelitian}

Dalam penelitian ini diawali dengan pendekatan kuantitatif, penetuan sumber data didahului dengan penentuan populasi dan sampel penelitian. Setelah hasil penelitian ini dikeatahui hasilnya, baru di tindak lanjuti dengan pendekatan kualitatif.

1. Populasi

Populasi dari penelitian ini adalah seluruh siswa di Sekolah SMPN 23 Kota Tangerang. Sedangkan jumlah siswa atau keseluruhan populasi adalah 1427 siswa, sedangkan yang diambil untuk penelitian sekitar 105 siswa yang terdiri dari kelas kelas 8 dan kelas 9, sebagaimana yang tertuang dalam tabel sebagai berikut ini :

Tabel. 1

\section{Populasi Penilitian}

\begin{tabular}{|l|c|c|}
\hline No. & Siswa & Jumlah \\
\hline 1. & Kelas 9 & 46 \\
2. & Kelas 8 & 59 \\
\hline \multicolumn{2}{|c|}{ Jumlah } & 105 \\
\hline
\end{tabular}

2. Penentuan jumlah sampel penelitian.

Besarnya sampel yang digunakan dalam penelitian ini adalah menggunakan rumus tabel Krejcie Morgan dengan taraf signifikansi 95\% dengan jumlah 105 orang, maka sampel minimal yang diambil adalah 100 orang.

Tabel. 2

Sampel Penelitian

\begin{tabular}{|l|l|c|l|}
\hline No & Kelas & Populasi & Sampel \\
\hline 1. & Kelas 9 & 46 & $46 / 105 \times 100=43,8 \%$ \\
\hline & Kelas 8 & 59 & $59 / 105 \times 100=56,2 \%$ \\
\hline \multicolumn{2}{|l|}{ jumlah } & 105 & $100 \%$ \\
\hline
\end{tabular}




\section{F. Teknik Pengumpulan Data}

1. Cara pengumpulan data

Penelitian ini menggunakan beberapa alat untuk mengumpulkan data yang beragam. Alat yangdigunakan adalah sebagai berikut:

a. Quesioner

Metode ini digunakan dengan menggunakan daftar pernyataan maupun pertanyaan diberikan kepada responden. Metodeini merupakan metode utama pengumpulan data.

b. Wawancara

Metode ini digunakan untuk memperkaya informasi yang telah dikumpulkan dengan quesioner.

c. Dokumentasi

Metode dokumentasi adalah cara pengumpulan data dengan mempergunakan dokumen-dokumen sebagai sumber data. ${ }^{12}$

Untuk memperoleh data yang dibutuhkan diperlukan alat pengumpul yang berupa angket atau questioner secara tertutup yang terdiri dari lima option alternative jawaban dengan menggunakan skala likert 1 sampai 5 yang dimodifikasi skala sikap dengan menghilangkan pernyataan negative.

Adapun materi antar variabel dapat diukur melalui angket (questioner) dengan pendekatan aspek dan indikator seperti pada tabel berikut:kinerja sebagai berikut:

Tabel.3

Penetapan Skor Jawaban Angket Skala Likert

\begin{tabular}{|c|c|l|l|}
\hline No. & Nilai & \multicolumn{1}{|c|}{ Kriteria } & \multicolumn{1}{c|}{ Tanggapan } \\
\hline 1 & 5 & Sangat baik/Tinggi & Sangat setuju \\
\hline 2 & 4 & Baik/Tinggi & Setuju \\
\hline 3 & 3 & Cukup & Ragu-ragu \\
\hline 4 & 2 & Tidak baik/rendah & Tidak setuju \\
\hline 5 & 1 & $\begin{array}{l}\text { Sangat tidak baik/sangat } \\
\text { rendah }\end{array}$ & Sangat tidak setuju \\
\hline
\end{tabular}

Hasil uji validitas menunjukan semua butir angket valid, karena $\mathrm{r}$ hitung secara keseluruhan butir lebih dari $\mathrm{r}$ tabel, $\mathrm{n}=70$ sebesar 0,235. Adapun hasil output SPSS mengenai uji validitas instrument secara rinci ada pada lampiran 3, sedangkan secara ringkas dapat dilihat pada tabel 3.5 berikut ini:

Tabel.4

\section{Hasil uji Validitas Instrument}




\begin{tabular}{|c|l|c|c|c|}
\hline No & \multicolumn{1}{|c|}{ Variabel } & $\begin{array}{c}\text { Jumlah } \\
\text { butir }\end{array}$ & Valid & $\begin{array}{c}\text { Tidak } \\
\text { valid }\end{array}$ \\
\hline 1 & Perilaku Akhlak Siswa & 63 & 63 & 0 \\
\hline 2 & $\begin{array}{l}\text { Manajemen Berbasis } \\
\text { Sekolah }\end{array}$ & 63 & 63 & 0 \\
\hline 3 & $\begin{array}{l}\text { Pengelolaan Pembelajaran } \\
\text { PAI }\end{array}$ & 63 & 63 & 0 \\
\hline
\end{tabular}

Memperhatikan analisis kualitas validitas instrumen penelitian tersebut diatas, maka penafsiran hasil analisis validitas setiap instrumen adalah sebagai berikut:

1. Pengujian validitas instrumen perilaku akhlaq siswa (Y)

Instrumen variabel $\mathrm{Y}$ dalam penelitian ini mengungkap hasil mutu pendidikan yang tercermin pada perilaku akhlaq siswa dengan menggunakan 70 item dengan menggunakan seratus responden. Instrumen ini akan di gunakan untuk mengukur mutu pembentukan akhlaq siswa di sekolah SMPN 23 Kota Tangerang.

Setelah dilakukan penelitian pengujian dengan analisis program SPSS versi 17 for window di peroleh hasil sebagai berikut:

1. Skor yang valid mencapai 63 item.

2. Skor yang tidak valid 7 item

Uji validitas di atas memberikan gambaran bahwa instrument mutu pendidikan memiliki validitas yang baik, karena dari 70 item yang memiliki kualitas yang baik sebanyak 63 item dengan nilai rata-rata di atas 0,230. Dengan demikian bila ditinjau dari aspek validitas, maka instrumen variabel mutu sekolah memenuhi syarat sebagai instrument penelitian.

3. Pengujian Validitas Instrumen Pengelolaan Pembelajaran pendidikan Agama Islam (X )

Intrumen variabel $\mathrm{X}$ dalam penelitian ini mengungkapkan pengelolaan pembelajaran yang menggunakan 70 item. Instrumen ini akan digunakan untuk mengukur tingkat pengelolaan pembelajaran. Setelah dilakukan pengujian dengan menggunakan program SPSS versi17 di peroleh hasil sebagai berikut :

1. Skor yang valid mencapai 63 item.

2. Skor yang tidak valid 7 item

Hasil dari uji validits instrument di atas memberikan gambaran bahwa instrumen pengelolaan pembelajaran PAI memiliki validitas yang baik, karena dari 70 item yang memiliki validitas baik sekitar 63 item yaitu dengan nilai skor di atas 0,230. Dengan demikian bila ditinjau dari aspek validitas, maka instrumen pengelolaan pembelajaran memenuhi syarat sebagai instrumen penelitian.

4). Pengujian Reliabilitas

Uji Pengujian reliabilitasi instrumen dalam suatu penelitian sangat perlu dilakukan karena rehabilitas berkaitan dengan" keajegan " dan taraf kepercayaan terhadap instrumen tersebut. Menguji rehabilitas alat ukur sama dengan menguji konsitensi.

Instrumen dalam penelitian ini masing-masing memiliki lebih dari 3 alternatif dapat digunakan dalam proses SPSS. 
Penentuan tingkat reliabilitas intrumen menurut fernandes dalam Saifudin Azwar ${ }^{13}$ dinyatakan bahwa reliabilitas minimal 0,5. Hal ini mengandung pengertian bahwa suatu instrumen dapat digunakan sebagai pengumpul data yang handal, koefisien realibilitas dapat dipergunakan katagori reliabilitas dengan rentangan sebagai berikut :

Tabel

Kriteria Realibilitas

\begin{tabular}{|c|c|c|}
\hline No & Koefisien & \\
\hline 1 & $0,81-1,00$ & Sangat tinggi \\
\hline 2 & $0,61-080$ & Tinggi \\
\hline 3 & $0,41-0,60$ & cukup \\
\hline 4 & $0,21-0,40$ & rendah \\
\hline 5 & $0,00-0,20$ & Sangat rendah \\
\hline
\end{tabular}

Mengacu pada criteria di atas, maka dapat diuji reliabilitas,dalam pengujian reliabilitas yang diuji hanya item yang mempunyai kriteria dan sudah teruji validtasnya, item yang tidak valid tidak di ikut sertakan.

Dalam penelitian ini untuk menguji reliabilitas menggunakan rumus Alpha Conbach. Jika $\mathrm{r}$ hitung lebih besar dari $\mathrm{r}$ tabel maka instrument dikatakan reliable. Pengelolaan data untuk uji reliabilitas dalam penelitian ini menggunakan komputer program SPSS versi 17. Adapun hasil uji reliabilitas secara ringkas dapat dilihat pada tabel berikut:

Tabel

Hasil Uji Relibilitas instrument

\begin{tabular}{|l|l|l|l|l|}
\hline No. & Variabel & $\mathrm{r}$ hitung & $\mathrm{r}$ tabel & kesimpulan \\
\hline 1. & $\begin{array}{l}\text { Mutu sekolah } \\
\text { (Perilaku akhlak) }\end{array}$ & 0,965 & 0,230 & Reliabel \\
2. & $\begin{array}{l}\text { Pengelolaan } \\
\text { Pembelajaran } \\
\text { PAI }\end{array}$ & 0,965 & 0,230 & Reliabel \\
\hline
\end{tabular}

Tabel di atas menggambarkan bahwa semua variabel penelitian dari mutu pendidikan (perilaku akhlak siswa), dan pengelolaan pembelajaran menunjukkan reliabel sehingga layak untuk dilanjutkan peneltian.

Adapun secara rinci hasil penelitian ini sebagai berikut:

a). Pengujian Reliabilitas Instrumen Mutu Sekolah Dalam Perilaku AkhlakSiswa (Y)

Instrumen variabel $\mathrm{Y}$ dalam penelitian ini mengungkap mutu sekolah yang menggunakan 63 item. Instrumen ini digunakan untuk mengukur mutu sekolah yang diuji realibilitasnya menggunakan program SPSS dengan formula koefesien alpha. 
Hasil koefesien realibilitas instrumen ini diperoleh koefesien alpha sebesar 0,965 yang berarti masuk pada kategori memiliki reabilitas sangat tinggi, sehingga layak untuk dilakukan pengumpulan data.

c). Pengujian Realibilitas Instrumen Pengelolaan Pembelajaran Agama Islam (X)

Instrumen variabel $\mathrm{X}$ dalam penelitian ini mengungkapkan pengelolaan pembelajaran agama Islam yang menggunakan 63 item. Instrumen ini akan digunakan untuk mengukur pengelolaan pembelajaran agama Islam yang diuji reabilitasnya menggunakan program SPSS dengan formula koefisien Apha.

Hasil analisis reliabilitas instrumen ini diperoleh koefesien sebesar 0,965 yang berarti layak untuk digunakan untuk pengumpulan data.

\section{Analisis Regresi Korelasional}

Hubungan fungsional dan variabel devendent dengan variabel indevendent dilakukan dengan regresi sederhana. Model regresi yang digunakan adalah regresi model linier dengan model sebagai berikut:

$$
\begin{aligned}
& \mathrm{Y}=\mathrm{a}+\mathrm{b}_{1} \mathrm{X}_{1} \quad \text { Dimana: } \\
& \mathrm{Y}=\text { Perilaku Siswa } \\
& \mathrm{X}=\text { Pengelolaan Pendidikan Agama Islam } \\
& \mathrm{a}=\text { Konstanta } \\
& \mathrm{b}=\text { Koefesien Regresi }
\end{aligned}
$$

Model persamaan yang diperoleh dari pengelolaan data diupayakan agar bisa bebas dari penyimpangan asumsi klasik. Untuk itulah pada penelitian ini juga akan dilakukan pengujian terhadap penyimpangan dari asumsi klasik. Pengujian yang dilakukan meliputi :

\section{a. Uji Persyaratan}

Uji persayaratan dalam regresi digunakan adalah pengujian normalitas data setiap variabel dan pengujian linieritas variabel $\mathrm{X}$ dan $\mathrm{Y}$.

\section{b. Uji Hipotesis}

Pengujian hipotesis akan dilakukan dengan uji koefesien $\mathrm{F}$ dengan tingkat signifikansi sebesar $5 \%$. Pengujian ini dengan kriteria sebagai :

1. Jika F- hitung $\geq F$ Tabel, Ho ditolak dan Ha diterima, berarti ada pengaruh yang signifikan antara variabel yang independen secara bersama terhadap variabel dependen.

2. Jika F- hitung $\leq$ F- tabel, Ho diterima dan Ha ditolak, berarti tidak ada pengaruh yang signifikan antara variabel independen secara bersama terhadap variabel dependen.

Pengujian Normalitas Masing-masing Variabel

Untuk pengujian normalitas data penelitian ini digunakan teknik analisis dengan memanfaatkan analisis komputer dengan fasilitas program SPSS versi 17. Penentuan normalitas setiap didasarkan pada nilai sebaran data yang diperoleh dari pengumpulan data. Dalam penelitian ini uji normalitas digunakan uji kolmogorov-smirnov, dengan criteria signifikasi untuk uji dua sisi hasil perhitungan bahwa suatu data dikategorikan memiliki sebaran yang normal apabila memiliki perhitungan yang lebih besar dari 0,5 berarti berdistribusi normal. 
Dari hasil uji normalitas menunjukkan bahwa nilai signifikasi setiap variabel masih di atas 0,5 , hal ini menunjukkan semua variabel menunjukkan berdistribusi normal, karena nilai sig lebih besar dari 0,5, sehingga layak untuk dianalisis dengan menggunakan rumus regresi. Adapun hasil uji normal masing-masing variabel adalah sebagai berikut:

b. Variabel Y (Perilaku Akhlak Siswa)

Hasil uji normalitas variabel Y (Perilaku Akhlak Siswa) sebagaimana tertuang dalam Tabel berikut:

Tabel

Tests of Normality

\begin{tabular}{|l|c|c|r|r|r|r|}
\hline & \multicolumn{2}{|c|}{ Kolmogorov-Smirnov $^{\mathrm{a}}$} & \multicolumn{3}{|c|}{ Shapiro-Wilk } \\
\cline { 2 - 7 } & $\begin{array}{c}\text { Statisti } \\
\mathrm{c}\end{array}$ & $\mathrm{df}$ & \multicolumn{1}{c|}{ Sig. } & Statistic & \multicolumn{1}{c|}{$\mathrm{df}$} & Sig. \\
\hline $\begin{array}{l}\text { Total } \\
\text { Jawaban }\end{array}$ & .084 & 100 & .077 & .978 & 100 & .096 \\
\hline
\end{tabular}

\section{a. Lilliefors Significance Correction}

Berdasarkan tabel 4.26 uji normalitas Kolmogorov-Smirnov variabel perilaku akhlak siswa (Y) di atas, diperoleh nilai signifikansi (Sig.) sebesar 0,77 hal ini menunjukkan bahwa nilai Sig. tidak signifikan terhadap $\alpha=0,05$. Karena Sig. $=0,77>$ $\alpha=0,05$ maka dapat disimpulkan bahwa penyebaran data pada variabel Perilaku Akhlak Siswa berdistribusi normal. Demikian juga hasil uji normalitas Shapiro-Wilk menunjukkan nilai Sig. tidak signifikan terhadap $\alpha=0,05$. Karena Sig. $=0,96>\alpha=$ 0,05 maka dapat disimpulkan bahwa penyebaran data pada variabel perilaku akhlak siswa berdistribusi normal.

Sedangkan cara grafis pengujian normalitas menggunakan Normal QQ-Plot adalah sebagai berikut:

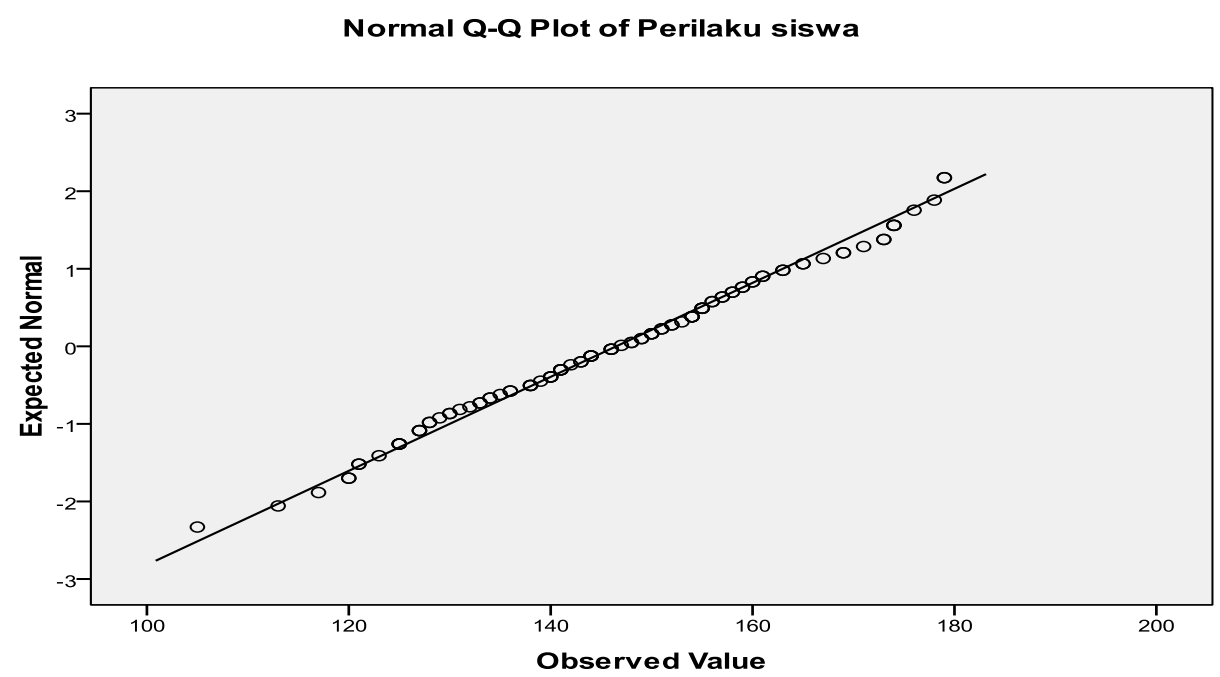

Berdasarkan grafik Normal QQ-Plot dengan menggunakan SPSS versi 17 terlihat bahwa sebaran data variabel Y (Perilaku akhlak siswa) cenderung mengikuti 
(menempel) garis normal. Hal ini dapat disimpulkan bahwa sebaran data Perilaku akhlak Siswa (Y)) berdistribusi normal.

Selanjutnya pengujian Detrended Normal Q-Q Plot sebagaimana disajikan pada gambar berikut ini:

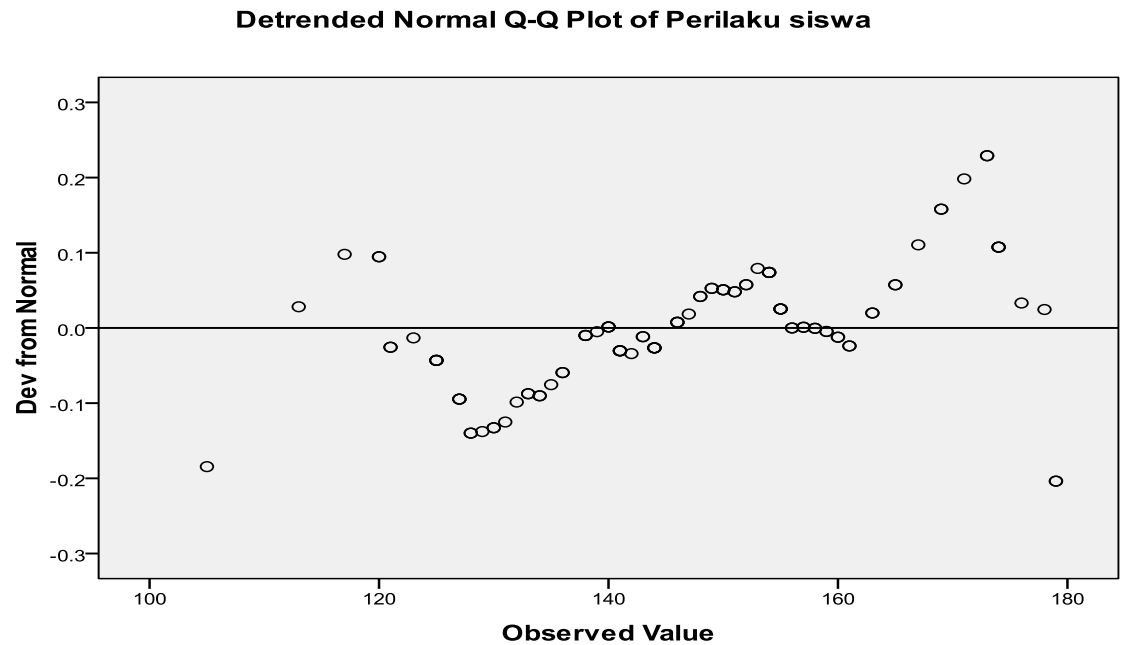

Demikian juga grafik Detrended Normal QQ-Plot menunjukkan sebaran data yang cenderung seimbang antara sebaran data diatas garis normal maupun sebaran data di bawah garis normal.

a. Variabel X2 (Pengelolaan Pembelajaran PAI)

Dari hasil uji normalitas menunjukkan bahwa nilai signifikasi setiap variabel $\mathrm{X} 2$ masih di atas 0,5, hal ini menunjukkan variabel menunjukkan berdistribusi normal, karena nilai sig lebih besar dari 0,5, sehingga layak untuk dianalisis dengan menggunakan rumus regresi. Adapun hasil uji normalitas variabel x2 adalah sebagai berikut:

Tabel

Tests of Normality

\begin{tabular}{|l|c|c|r|r|r|r|}
\hline & \multicolumn{2}{|c|}{ Kolmogorov-Smirnov $^{\text {a }}$} & \multicolumn{3}{|c|}{ Shapiro-Wilk } \\
\cline { 2 - 7 } & $\begin{array}{c}\text { Statisti } \\
\mathrm{c}\end{array}$ & \multicolumn{1}{c|}{$\mathrm{df}$} & Sig. & Statistic & \multicolumn{1}{c|}{$\mathrm{df}$} & Sig. \\
\hline $\begin{array}{l}\text { Total } \\
\text { Jawab } \\
\text { an }\end{array}$ & .084 & 100 & .077 & .978 & 100 & .096 \\
\hline
\end{tabular}

a. Lilliefors Significance Correction

Berdasarkan tabel 4.26 uji normalitas Kolmogorov-Smirnov variabel perilaku akhlak siswa (Y) di atas, diperoleh nilai signifikansi (Sig.) sebesar 0,77 hal ini menunjukkan bahwa nilai Sig. tidak signifikan terhadap $\alpha=0,05$. Karena Sig. $=0,77>$ $\alpha=0,05$ maka dapat disimpulkan bahwa penyebaran data pada variabel Perilaku Akhlak Siswa berdistribusi normal. Demikian juga hasil uji normalitas Shapiro-Wilk menunjukkan nilai Sig. tidak signifikan terhadap $\alpha=0,05$. Karena Sig. $=0,96>\alpha=$ 0,05 maka dapat disimpulkan bahwa penyebaran data pada variabel perilaku akhlak siswa berdistribusi normal 
Kemudian pengujian normalitas dalam penelitian ini dilanjutkan dengan grafik Normal Q-Q Plot dengan menggunakan SPSS versi 17 sehingga mendapatkan hasil Sebagaimana terdapat pada gambar berikut ini:

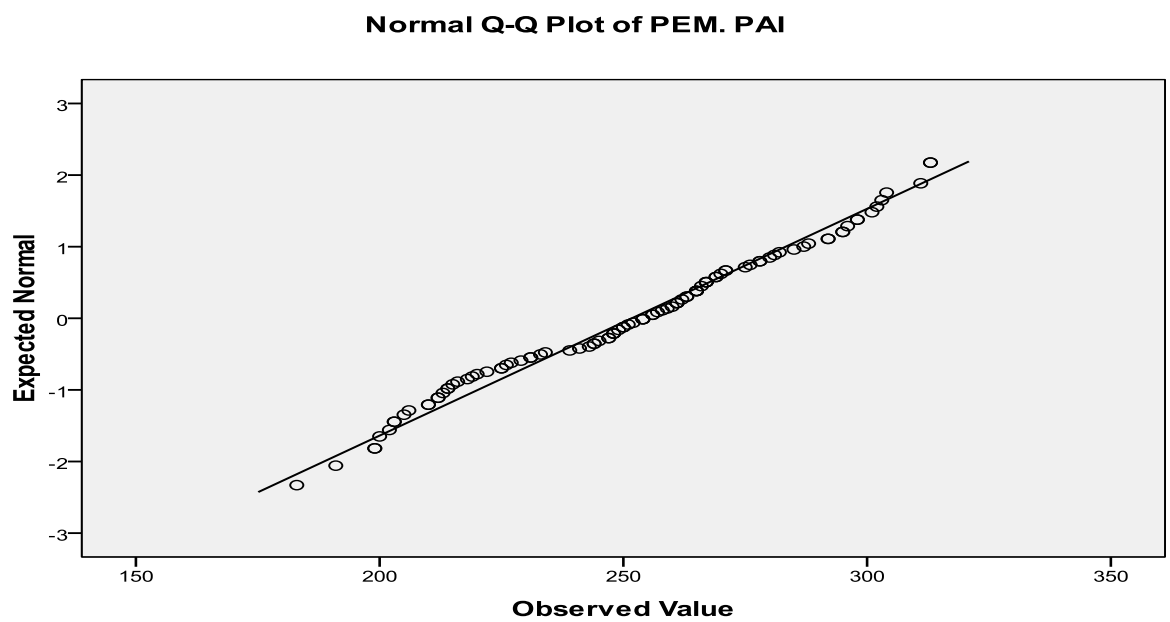

Berdasarkan grafik Normal QQ-Plot dengan menggunakan SPSS versi 17 terlihat bahwa sebaran data variabel X2 (Pengelolaan Pembelajaran PAI) cenderung mengikuti (menempel) garis normal. Hal ini dapat disimpulkan bahwa sebaran data Pengelolaan Pembelajaran PAI (X2)) berdistribusi normal. Sedangkan penyebaran data pada Detrended Normal Q-Q Plot sebagai berikut:

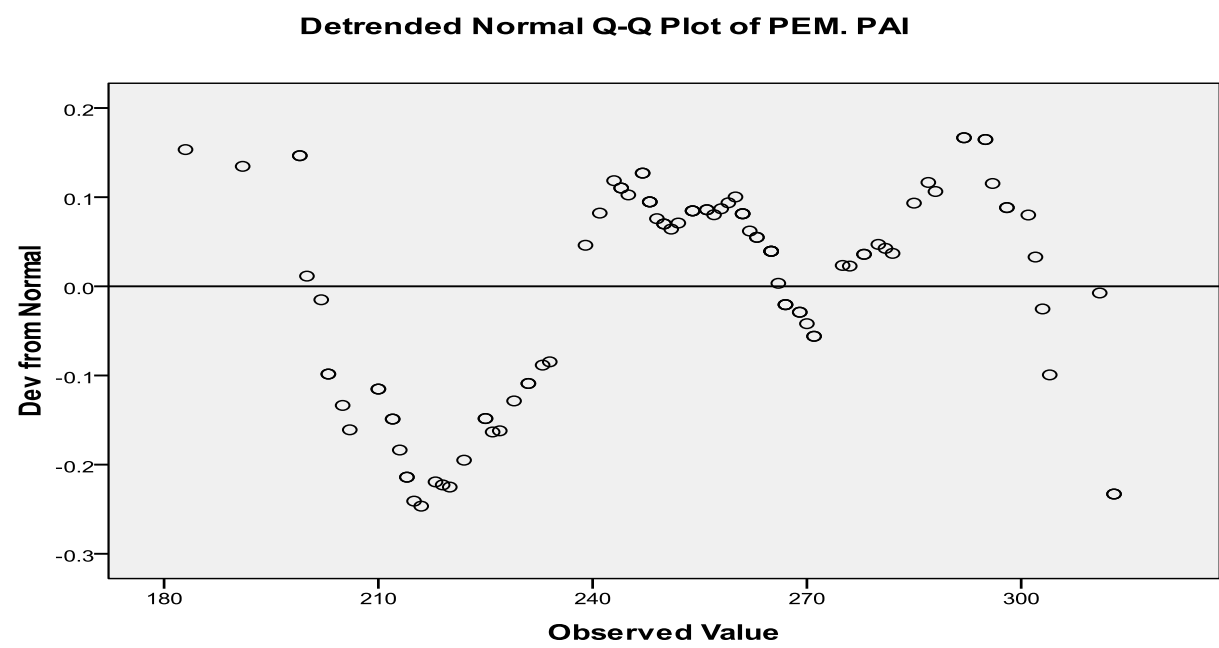

Demikian juga grafik Detrended Normal QQ-Plot menunjukkan sebaran data yang cenderung seimbang antara sebaran data diatas garis normal maupun sebaran data di bawah garis normal. Yang berarti grafik Detrended Normal QQ-Plot menunjukkan sebaran data berdistribusi normal.

2). Pengujian linieritas $\mathrm{X} 2$ (Pengelolaan Pembelajaran PAI) terhadap Y (Perilaku Siswa) 
Linieritas variabel X2 (Pengelolaan Pembelajaran PAI) terhadap variabel Y (Peilaku Siswa) tidak lain adalah untuk menguji garis regresi yang dibentuk dari variabel X2 dengan variabel Y. Hasil analisis sebagai berikut:

Tabel

Ringkasan Analisis of Variance Linieritas Variabel X

\begin{tabular}{|l|r|r|r|r|l|}
\hline & \multicolumn{1}{|c|}{ ANOVAb of } \\
Model & Squares & df & $\begin{array}{c}\text { Mean } \\
\text { Square }\end{array}$ & F & Sig. \\
\hline Regression & 24192.499 & 1 & 24192.499 & 858.856 & $.000 \mathrm{a}$ \\
Residual & 2760.491 & 98 & 28.168 & & \\
Total & 26952.990 & 99 & & & \\
\hline
\end{tabular}

a. Predictors: (Constant), PEM. PAI

Dependent Variable: Perilaku siswa

Coefficients $_{\mathbf{a}}$

\begin{tabular}{|c|c|c|c|c|c|}
\hline \multirow{2}{*}{ Model } & \multicolumn{2}{|c|}{$\begin{array}{c}\text { Unstandardized } \\
\text { Coefficients }\end{array}$} & $\begin{array}{c}\text { Standardized } \\
\text { Coefficients }\end{array}$ & & \\
\cline { 2 - 4 } & $\mathrm{B}$ & Std. Error & Beta & $\mathrm{t}$ & Sig. \\
\hline (Constant) & 21.850 & 4.286 & & 5.098 & .000 \\
Pem. PAI & .495 & .017 & .947 & 29.306 & .000 \\
\hline
\end{tabular}

a. Dependent Variable: Perilku Akhlak siswa

Bberdasarkan tabel tersebut di atas menunjukkan bahwa harga $\mathrm{F}$ deviance from linierity hasil observasi sebesar 858.856 apabila dibandingkan dengan nilai $\mathrm{F}$ tabel pada taraf signifikasi 95\% >0,05 yang berarti nonsignifikan. Dapat juga dilihat dari nilai signifikansinya apabila nilai signifikansinya $<0,05$ maka dapat disimpulkan

Bahwa uji regresi yang dilakukan bersifat linier. Hal ini menunjukkan bahwa variabel $\mathrm{X}$ memiliki hubungan yang linier dengan variabel $\mathrm{Y}$.

\section{G. Uji Hipotesis: Pengaruh Pengelolaan Pembelajaran PAI (X) Terhadap Perilaku Akhlak Siswa (Y)}

Untuk Menguji besarnya pengaruh pembelajaran PAI terhadap perilaku Siswa secara parsial digunakan analisis regresi sederhana. Dengan bantuan software komputer program SPSS versi 17. Sebelum menentukan besarnya pengaruh variabel pengelolaan pembelajaran PAI terhadap perilaku siswa, maka akan dianalisis terlebih dahulu mengenai keeratan hubungan dua variabel tersebut. 
Berdasarkan output komputer mengenai koefesion korelasi, diperoleh koefesion sebesa 0,947 (.pada tabel coefesien di bawah) dan koefesion ini bertanda fositif. Ini menggambarkan jika pengelolaan pembelajaran PAI meningkat (lebih baik) maka perilaku akhlak siswa akan meningkat pula. Model hubungan pengelolaan pembelajaran PAI dengan perilaku akhlak siswa adalah signifikan, hal ini ditunjukan oleh besarnya uji- $\mathrm{t}=29.306$ lebih besar jika dibandingkan dengan $\mathrm{t}$ tabel alpha 0,05

$(\mathrm{df}=100)$ sebesar 1.658 Hasil uji-t untuk model regresi sederhana ini dapat mengestimasi perilaku akhlak siswa dapat ditentukan oleh pengelolaan pembelajaran PAI.

Adapun hasil uji-t berdasarkan output komputer dapat dilihat seperti berikut:

\section{Coefficients $_{\mathbf{a}}$}

\begin{tabular}{|c|c|c|c|c|c|}
\hline \multirow[b]{2}{*}{ Model } & \multicolumn{2}{|c|}{$\begin{array}{c}\text { Unstandardized } \\
\text { Coefficients } \\
\end{array}$} & \multirow{2}{*}{$\begin{array}{c}\begin{array}{c}\text { Standardized } \\
\text { Coefficients }\end{array} \\
\text { Beta }\end{array}$} & \multirow[b]{2}{*}{$\mathrm{t}$} & \multirow[b]{2}{*}{ Sig. } \\
\hline & B & Std. Error & & & \\
\hline$($ Constant $)$ & 21.850 & 4.286 & & 5.098 & .000 \\
\hline Pem. PAI & .495 & .017 & .947 & 29.306 & .000 \\
\hline
\end{tabular}

a. Dependent Variable: Perilku Akhlak siswa

Berdasarkan output di atas diperoleh koefesion regresi sebesar 0,495 dan konstanta sebesar 21.850. Maka dapat digambarkan bentuk hubungan kedua variabel pengelolaan pembelajaran PAI dengan perilaku siswa dalam bentuk persamaan regresi $\mathrm{Y}=21.850+0.495 \mathrm{X}$. Ini berarti bahwa jika pengelolaan pembelajaran PAI meningkat sebesar 1 poin maka perilaku akhlak siswa akan meningkat 0,495 poin.

Dapat dikatakan pula bahwa pengelolaan pembelajaran PAI meningkat maka perilaku akhlak siswa meningkat lebih baik. Hubungan ini juga linier, hal ini dijelaskan dengan hasil uji F melalui output komputer Sig 0,000 < 0,05. Ini dapat dikatakan pula model regresi adalah model yang dapat mengestimasi perilaku akhlak siswa yaitu pengaruhnya positif dan signifikan. Untuk lebih jelasnya hasil uji $\mathrm{F}$ melalui output komputer :

ANOVAb

\begin{tabular}{|l|r|r|r|r|r|}
\hline Model & \multicolumn{1}{|c|}{$\begin{array}{c}\text { Sum of } \\
\text { Squares }\end{array}$} & df & Mean Square & F & Sig. \\
\hline${ }^{1}$ Regression & 24192.499 & 1 & 24192.499 & 858.856 & $.000 \mathrm{a}$ \\
Residual & 2760.491 & 98 & 28.168 & & \\
Total & 26952.990 & 99 & & & \\
\hline
\end{tabular}

a. Predictors: (Constant), PEM. PAI

b. Dependent Variable: Perilaku siswa

Adapun besarnya pengaruh pengelolaan pembelajaran PAI terhadap perilaku siswa dapat dilihat pada output computer berikut: 


\section{Model Summary}

\begin{tabular}{|l|c|r|r|r|}
\hline Model & $\mathrm{R}$ & $\mathrm{R}$ Square & $\begin{array}{c}\text { Adjusted R } \\
\text { Square }\end{array}$ & Std. Error of the Estimate \\
\hline 1 & $.947 \mathrm{a}$ & .898 & .897 & 5.307 \\
\hline
\end{tabular}
a. Predictors: (Constant), PEM. PAI
b. Dependent: Perilaku Akhlak Siswa

Berdasarkan output computer di atas dapat dijelaskan bahwa diperoleh nilai $\mathrm{R}$ square sebesar 0.898. Hal ini berarti bahwa variabel pengelolaan pembelajaran PAI berpengaruh terhadap perilaku akhlak siswa sebesar 89,8\% dan sisanya sebesar $11,3 \%$ ditentukan oleh sebab lain diluar model regresi sederhana atau pengujian parsial tersebut. Pengelolaan pembelajaran PAI lebih dominan dibandingkan dengan manajemen berbasis sekolah. Adapun pengaruh variabel pengelolaan pembelajaran PAI terhadap perilaku akhlak siswa adalah signifikan yaitu diperoleh hasil uji $\mathrm{F}$ melalui output computer sig $0,000<0,05$.

\section{H. Kesimpulan} bahwa:

Dari hasil penelitian yang telah disajikan dalam bagian sebelumnya dapat disimpulkan

Variabel pengelolaan pembelajaran adalah salah satu variabel yang memiliki pengaruh positif dan signifikan terhadap mutu sekolah. Pengaruh yang signifikan dapat diperhatikan dari nilai t sebesar 3,668 yang lebih besar dari t tabel sebesar 1,658. Sedang pengaruh yang positif dapat kita perhatikan dari koefesien korelasi parsial sebesar 0,311 yang bernialai positif.

Koefesien ini menunjukkan bahwa variabel pengelolaan pembelajaran memiliki pengaruh yang positif terhadap variabel mutu sekolah. Lebih jauh dapat diterjemahkan semakin baik kualitas pengelolaan pembelajaran semakin baik mutu sekolah, sebaliknya semakin rendah kualitas pengelolaan pembelajaran semakin rendah pula mutu sekolah. Jika diperhatikan $\mathrm{R}^{2}$ sebesar 0,898 , nilai ini memberikan gambaran bahwa sumbangan efektif yang diberikan oleh variabel pengelolaan pembelajaran terhadap mutu sekolah SMPN 23 Kota Tangerang sebesar $89,8 \%$.

\section{DAFTAR PUSTAKA}

[1] Al- Abrasyi, M. Athiyah alih bahasa, A. Gani dan Djohar Bahry, Dasar-Dasar Pokok Pendidikan Islam, PT.Bulan Bintang,jakarta, 1970. Hal, 163.

[2] Azwar, Saifuddin. Reliabilitas dan Validitas. Yogyakarta : Pustaka Pelajar, 2008. Hambal, Ahmad bin, Musnad Ahmad, jilid II, tt.

Al Munawir, Ahmad Warson, Kamus Bahasa Arab Indonesia, Yogyakarta: Pustaka Progresif, Tahun 1997.

[3] Mukhlisin, Pengaruh Pemahaman PAI Terhadap Perilaku Sosial Siswa di SMK Unggulan NU Mojoagung Jomban, Jurnal Pendidikan Islam (E-ISSN: 2550-1038), Vol. 1, No. 2, Desember 2017, Hal. 215-234. Website: journal.Unipdu.ac.id/index.php/jpi/index.

[4] Sri Sapitri Aryanti, Pengaruh Aktivitas Pembelajaran Pendidikan Agama islam Terhadap Akhlak Siswa(Penelitian di SMP Negeri 3 Karang Pawitan Garut) Jurnal Pendidikan 
Universitas Garut Fakultas Pendidikan Islam dan Keguruan Universitas Garut ISSN: 1907-932X 44

[5] Syaiful Anwar, Peran Pendidikan Agama Islam Dalam Membentuk Karakter Bangsa, AlTadzkiyyah: Jurnal Pendidikan Islam, Volume 7, November 2016 P. ISSN: 20869118 EISSN: 2528-2476 157

[6] Sukmara, Dian, Implementasi Life Skill dalam KTSP, Mugni Sejahtera, Tahun, 2007.

Suhada, Buku Ajar Pendidikan Agama Islam Untuk Perguruan Tinggi, Yogyakarta: Deepublish (CV. Budi Utama), Tahun 2018.

, Tesis: Korelasi Manajemen Berbasis Sekolah Dan Pengelohan Pembelajaran Pendidikan Agama Islam Terhadap Perilaku Akhlak siswa, PTIQ Jakarta Tahun 2014.

1). Sri Sapitri Aryanti, Pengaruh Aktivitas Pembelajaran Pendidikan Agama islam Terhadap Akhlak Siswa(Penelitian di SMP Negeri 3 Karang Pawitan Garut) Jurnal Pendidikan Universitas Garut Fakultas Pendidikan Islam dan Keguruan Universitas Garut ISSN: 1907-932X 44

2). Mukhlisin, Pengaruh Pemahaman PAI Terhadap Perilaku Sosial Siswa di SMK Unggulan NU Mojoagung Jomban, Jurnal Pendidikan Islam (E-ISSN: 2550-1038), Vol. 1, No.

2, Desember 2017, Hal. 215-234. Website:journal.Unipdu.ac.id/index.php/jpi/index.

3). Syaiful Anwar, Peran Pendidikan Agama Islam Dalam Membentuk Karakter Bangsa, AlTadzkiyyah: Jurnal Pendidikan Islam, Volume 7, November 2016 P. ISSN: 20869118 EISSN: 2528-2476 157

4). W.J.S. Purwadarminta, kamus umum bahasa Indonesia, Balai pustaka, Jakarta,Tahun 1991 h. 738.

5). Ahmad Warson Al Munawir, Kamus Bahasa Arab Indonesia, Yogyakarta: Pustaka Progresif, Tahun 1997,h. 364.

6). W.J.S. Purwadarminta, Kamus umum bahasa Indonesia,...h. 955.

7). Ahmad bin Hambal, Musnad Ahmad, jilid II, h. 381, Al-Bukhari dalam al-Adabul Mufrad no. 273 (Shahiihul Adabil Mufrad no. 207), Ahmad (II/381), dan al-Hakim (II/613)

8). Dian Sukmara, Implementasi Life Skill dalam KTSP, Mugni Sejahtera, Tahun, 2007, h. 9.

9). M. Athiyah al- Abrasyi alih bahasa, A. Gani dan Djohar Bahry, Dasar-Dasar Pokok Pendidikan Islam, PT.Bulan Bintang,jakarta, 1970. Hal, 163.

10). M. Athiyah al- Abrasyi, Alih Bahasa A.Gani dan Djohar Bahri... 1970, hal.163.

11). M. Athiyah al- Abrasy,alih bahasa, A. Ghani,dan Djohar Bahri, ... hal.105-109.

12). Sugiyono, Memahami Penelitian Kualitatif, Alfabeta, Bandung, 2005, hlm. 320.

13). Saifuddin Azwar 2008. Reliabilitas dan Validitas. Yogyakarta : Pustaka Pelajar. 